\title{
Author Correction: Rationalizing the light-induced phase separation of mixed halide organic-inorganic perovskites
}

Sergiu Draguta1, Onise Sharia², Seog Joon Yoon ${ }^{1,3}$, Michael C. Brennan', Yurii V. Morozov', Joseph S. Manser ${ }^{2,3}$, Prashant V. Kamat ${ }^{1,2,3}$, William F. Schneider ${ }^{1,2} \&$ Masaru Kuno ${ }^{1}$

Correction to: Nature Communications https://doi.org/10.1038/s41467-017-00284-2, published online 04 Aug 2017

The original version of this Article contained an error in the spelling of the author Joseph S. Manser, which was incorrectly given as Joseph M. Manser. This has now been corrected in both the PDF and HTML versions of the Article.

Published online: 11 January 2018

\footnotetext{
(c) (i) Open Access This article is licensed under a Creative Commons Attribution 4.0 International License, which permits use, sharing, adaptation, distribution and reproduction in any medium or format, as long as you give appropriate credit to the original author(s) and the source, provide a link to the Creative Commons license, and indicate if changes were made. The images or other third party material in this article are included in the article's Creative Commons license, unless indicated otherwise in a credit line to the material. If material is not included in the article's Creative Commons license and your intended use is not permitted by statutory regulation or exceeds the permitted use, you will need to obtain permission directly from the copyright holder. To view a copy of this license, visit http://creativecommons.org/licenses/by/4.0/.
}

(c) The Author(s) 2018

\footnotetext{
${ }^{1}$ Department of Chemistry and Biochemistry, University of Notre Dame, Notre Dame, IN 46556, USA. ${ }^{2}$ Department of Chemical and Biomolecular Engineering, University of Notre Dame, Notre Dame, IN 46556, USA. ${ }^{3}$ Notre Dame Radiation Laboratory, University of Notre Dame, Notre Dame, IN 46556, USA. Sergiu Draguta and Onise Sharia contributed equally to this work. Correspondence and requests for materials should be addressed to

W.F.S. (email: wschneider@nd.edu) or to M.K. (email: mkuno@nd.edu)
} 